\title{
Tracking Stress Granule Dynamics in Live Cells and In Vivo with a Small Molecule
}

Wen Shao, Shu-Tang Zeng, Ze-Yi Yu, Gui-Xue Tang, Shuo-Bin Chen, Zhi-Shu Huang, Xiu-Cai Chen* and Jia-Heng Tan*

Guangdong Provincial Key Laboratory of New Drug Design and Evaluation, School of Pharmaceutical Sciences, Sun Yat-sen University, Guangzhou, 510006, China

*E-mail: chenxc35@mail.sysu.edu.cn (Xiu-Cai Chen); tanjiah@mail.sysu.edu.cn (Jia-Heng Tan).

\section{Table of Contents:}

1 Experimental Section $\quad$ S3

$\begin{array}{ll}\text { 1.1 Synthesis and Characterization } & \text { S3 }\end{array}$

Scheme S1. Synthesis of TASG $\quad$ S3

Figure S1. ${ }^{1} \mathrm{H}$ NMR spectrum of TASG $\quad$ S5

Figure S2. ${ }^{13} \mathrm{C}$ NMR spectrum of TASG $\quad$ S5

Figure S3. HPLC analysis of TASG $\quad$ S6

Figure S4. HRMS spectrum of TASG

$\begin{array}{ll}1.2 \text { UV-Vis Absorption Studies } & \text { S7 }\end{array}$

$\begin{array}{ll}\text { 1.3 Fluorescence Studies } & \text { S7 }\end{array}$

$\begin{array}{ll}\text { 1.4 Fixed Cell Staining Experiments } & \text { S7 }\end{array}$

$\begin{array}{ll}1.5 \text { Live Cell Staining Experiments } & \text { S8 }\end{array}$

$\begin{array}{lc}\text { 1.6 Plasmid Transfection } & \text { S8 }\end{array}$

$\begin{array}{ll}1.7 \text { Cell Viability Studies } & \text { S8 }\end{array}$

$\begin{array}{ll}1.8 \text { RNA Extraction and Purification } & \text { S9 }\end{array}$

1.9 Purification of GFP-G3BP1 Protein and Preparation of RNA-G3BP1 Condensates S9

$\begin{array}{lr}\text { 1.10 Purification of Mammalian Stress Granule Cores } & \text { S9 }\end{array}$

1.11 S. cerevisiae Staining Experiments $\quad$ S9

$\begin{array}{ll}\text { 1.12 Drosophila tissue Staining Experiments } & \text { S10 }\end{array}$

$\begin{array}{lr}1.13 \text { C. elegans Staining Experiments } & \text { S10 }\end{array}$

$\begin{array}{ll}2 \text { Materials } & \text { S10 }\end{array}$ 
Figure S5. Imaging of live stressed HeLa cells stained with TASG excited at 561 or $640 \mathrm{~nm} \quad$ S11

Figure S6. Imaging of live stressed HeLa cells expressing GFP-nucleolin stained with TASG S11

Figure S7. 3D-SIM imaging of live stressed HeLa cells stained with TASG S11

Figure S8. Imaging of live stressed HeLa cells stained with TASG in variant concentrations and incubation times S12

Figure S9. Imaging of live HeLa cells stained with TASG under various stress-inducing conditions $\quad$ S12

Figure S10. Imaging of fixed HeLa cells stained with TASG under various stress-inducing conditions S13

Figure S11. Imaging of fixed stressed HeLa cells stained with TASG in variant concentrations and incubation times S13

Figure S12. Imaging of fixed stressed HeLa cells stained with TASG and SG immunofluorescence $\quad$ S14

Figure S13. Imaging of live HeLa cells treated with sodium arsenite for 20 or $60 \mathrm{~min}$ and stained with TASG S14

Figure S14. Quantification of the colocalization between TASG and SGs $\quad$ S15

Figure S15. Imaging of live HeLa cells treated with $\mathrm{NaCl}$ /sodium arsenite and stained with TASG $\quad \mathrm{S} 15$

$\begin{array}{ll}\text { Figure S16. Viability of HeLa cells exposed to TASG } & \text { S16 }\end{array}$

$\begin{array}{lr}\text { Figure S17. Photostability of TASG } & \text { S16 }\end{array}$

Figure S18. Time-lapse imaging of SG dynamics in live HeLa cells using TASG S16

Figure S19. Imaging of fixed HeLa cells stained with TASG after DNase I or RNase A treatment $\quad$ S17

Figure S20. UV spectra of TASG with or without RNA, GFP-G3BP1 or their complexes $\quad$ S17

Table S1. Fluorescence quantum yields of TASG with or without RNA, GFP-G3BP1 or their complexes S17

$\begin{array}{ll}\text { Figure S21. Viscosity dependent fluorescence of TASG } & \text { S18 }\end{array}$

$\begin{array}{lr}\text { Figure S22. Concentration-Dependent UV-Vis absorbance of TASG } & \text { S18 }\end{array}$

4 Reference $\quad$ S19 


\section{Experimental Section}

\subsection{Synthesis and Characterization}

Scheme S1. Synthesis of TASG

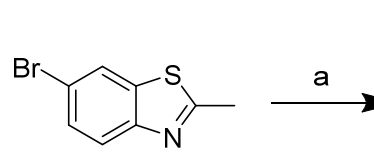<smiles>Cc1nc2ccc(N3CCN(C(=O)OCc4ccccc4)CC3)cc2s1</smiles>
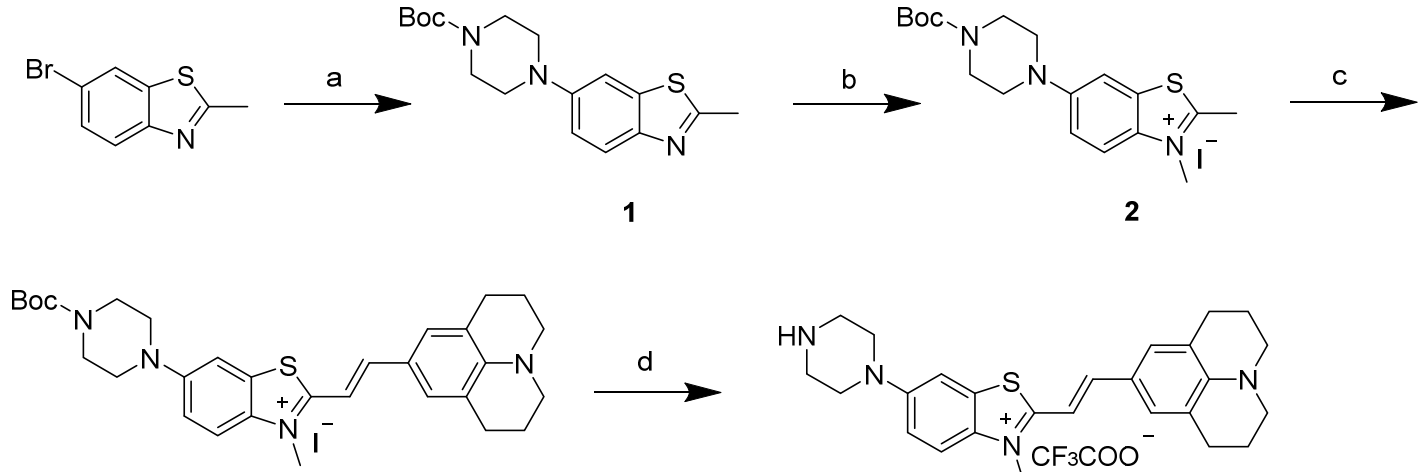

3

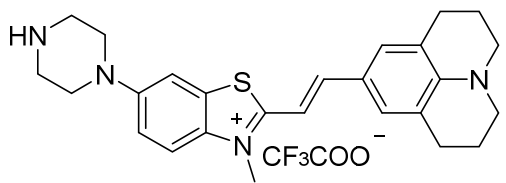

TASG

Reagents and conditions: (a) $\mathrm{N}$-Boc-piperazine, $\mathrm{Pd}_{2}(\mathrm{dba})_{3}$, Davephos, $\mathrm{Cs}_{2} \mathrm{CO}_{3}, 1,4$-dioxane, $\mathrm{Ar}, 95^{\circ} \mathrm{C}$, $24 \mathrm{~h}$; (b) $\mathrm{CH}_{3} \mathrm{I}$, acetonitrile, $70^{\circ} \mathrm{C}, 24 \mathrm{~h}$; (c) Julolidine aldehyde, $\mathrm{EtOH}, 80^{\circ} \mathrm{C}, 24 \mathrm{~h}$; (d) $\mathrm{CF}_{3} \mathrm{COOH}$, $\mathrm{CH}_{2} \mathrm{Cl}_{2}$, r.t., $12 \mathrm{~h}$.

${ }^{1} \mathrm{H}$ and ${ }^{13} \mathrm{C}$ NMR spectra were recorded on a Bruker Ascend ${ }^{\mathrm{TM}} 400$ spectrometer. Mass spectra (MS) were recorded on a Shimadzu LCMS-2010A instrument with an ESI or ACPI mass selective detector and high-resolution mass spectra (HRMS) were recorded on a Shimadzu LCMS-IT-TOF. Flash column chromatography was performed with silica gel (200-300 mesh) purchased from Qingdao Haiyang Chemical Co. Ltd. The purity of TASG was confirmed to be higher than $95 \%$ by using analytical HPLC performed with a dual pump Shimadzu LC-20 AB system equipped with an Ultimate XB-C18 column $(4.6 \times 250 \mathrm{~mm}, 5 \mu \mathrm{m})$ and eluted with methanol-water $(80: 20)$ containing $0.1 \%$ TFA at a flow rate of $0.4 \mathrm{~mL} \cdot \mathrm{min}^{-1}$. All chemicals were purchased from commercial sources unless otherwise specified. All the solvents were of analytical reagent grade and were used without further purification.

Synthesis of tert-butyl 4-(2-methylbenzo[ $[d]$ thiazol-6-yl)piperazine-1-carboxylate (1): To a stirred solution of 6-bromo-2-methylbenzothiazole $(1.0 \mathrm{~g}, 4.4 \mathrm{mmol})$ in anhydrous 1,4-dioxane, $N$-Bocpiperazine (3.7 g, $20.0 \mathrm{mmol}), \mathrm{Cs}_{2} \mathrm{CO}_{3}(3.9 \mathrm{~g}, 12.0 \mathrm{mmol}), \mathrm{Pd}_{2}(\mathrm{dba})_{3}(2.5 \mathrm{~mol} \%)$ and Davephos (2.5 mol\%), were added under argon in a sealed tube. The mixture was then stirred at $95^{\circ} \mathrm{C}$ for $24 \mathrm{~h}$. After cooling to room temperature, the mixture was filtered, and the solvent was evaporated under reduced pressure to afford a grayish yellow solid $\mathbf{1}$. The crude product was used in the next step without further purification. 


\section{Synthesis of 6-(4-(tert-butoxycarbonyl)piperazin-1-yl)-2,3-dimethylbenzo[d]|thiazol-3-ium iodide}

(2): A solution of $1(0.30 \mathrm{~g}, 0.90 \mathrm{mmol})$ in acetonitrile $(2.0 \mathrm{~mL})$ was treated with $\mathrm{CH}_{3} \mathrm{I}(0.2 \mathrm{~mL}, 3.4$ mmol). The mixture was heated at $70^{\circ} \mathrm{C}$ for $24 \mathrm{~h}$. After cooling to room temperature, the mixture was filtered, then the crude product was thoroughly washed with anhydrous ether and dried under vacuum to afford a yellow solid $2\left(0.34 \mathrm{~g}\right.$, yield 79\%). ${ }^{1} \mathrm{H}$ NMR (400 MHz, DMSO-d6) $\delta 8.09$ (d, $J=9.4 \mathrm{~Hz}$, 1H), $7.80(\mathrm{~d}, J=2.4 \mathrm{~Hz}, 1 \mathrm{H}), 7.56(\mathrm{dd}, J=9.4,2.5 \mathrm{~Hz}, 1 \mathrm{H}), 4.12$ (s, 3H), 3.55-3.46 (m, 4H), 3.31$3.26(\mathrm{~m}, 4 \mathrm{H}), 3.07$ (s, 3H), $1.43(\mathrm{~s}, 9 \mathrm{H})$. ESI-MS m/z: $348.2(\mathrm{M}-\mathrm{I})^{+}$.

Synthesis of (E)-6-(4-(tert-butoxycarbonyl)piperazin-1-yl)-3-methyl-2-(2-(2,3,6,7-tetrahydro$1 H, 5 H$-pyrido[3,2,1-ij]quinolin-9-yl)vinyl)benzo[d] thiazol-3-ium iodide (3): A mixture of 2 (0.10 $\mathrm{g}, 0.21 \mathrm{mmol})$ and julolidine aldehyde $(0.06 \mathrm{~g}, 0.30 \mathrm{mmol})$ in ethanol $(5.0 \mathrm{~mL})$ was stirred at reflux for $24 \mathrm{~h}$. After cooling to room temperature, the mixture was filtered, then the crude product was thoroughly washed with cool ethanol and dried under vacuum to afford a reddish brown solid $\mathbf{3}$. The crude product was used in the next step without further purification.

Synthesis of (E)-3-methyl-6-(piperazin-1-yl)-2-(2-(2,3,6,7-tetrahydro-1H,5H-pyrido[3,2,1ij]quinolin-9-yl)vinyl)benzo[d]thiazol-3-ium trifluoroacetate (TASG): Compound 3 (0.14 g, 0.20 mmol) was dissolved in a mixture of $\mathrm{CF}_{3} \mathrm{COOH} / \mathrm{CH}_{2} \mathrm{Cl}_{2}(1: 3)$, stirred at room temperature for $12 \mathrm{~h}$. After that, the mixture was concentrated under reduced pressure and then washed to afford a reddish brown solid TASG $\left(0.031 \mathrm{~g}\right.$, yield 28\%). ${ }^{1} \mathrm{H}$ NMR (400 MHz, DMSO- $\left.d_{6}\right) \delta 8.97(\mathrm{~s}, 1 \mathrm{H}), 7.92(\mathrm{~d}, J=$ $9.3 \mathrm{~Hz}, 1 \mathrm{H}), 7.83-7.74(\mathrm{~m}, 2 \mathrm{H}), 7.44(\mathrm{dd}, J=22.6,10.3 \mathrm{~Hz}, 4 \mathrm{H}), 4.14(\mathrm{~s}, 3 \mathrm{H}), 3.51$ (d, $J=4.9 \mathrm{~Hz}$, $4 \mathrm{H}), 3.35(\mathrm{dd}, J=11.6,6.1 \mathrm{~Hz}, 4 \mathrm{H}), 3.30(\mathrm{~s}, 4 \mathrm{H}), 2.73(\mathrm{t}, J=5.9 \mathrm{~Hz}, 4 \mathrm{H}), 1.94-1.86(\mathrm{~m}, 4 \mathrm{H}) .{ }^{13} \mathrm{C}$ NMR (101 MHz, DMSO-d6) $\delta 167.96,149.73,148.96,147.67,135.66,130.36$ (2C), 128.76, 121.47 (2C), 121.08, 118.37, 116.57, 108.71, 105.17, 50.03 (2C), 45.82 (2C), 42.93 (2C), 35.73, 27.44 (2C), 21.13(2C). Purity: $96.4 \%$ by HPLC. HRMS (ESI): calcd for $\left(\mathrm{M}-\mathrm{CF}_{3} \mathrm{COO}\right)^{+}\left(\mathrm{C}_{26} \mathrm{H}_{31} \mathrm{~N}_{4} \mathrm{~S}^{+}\right) 431.2264$, found 431.2252 . 


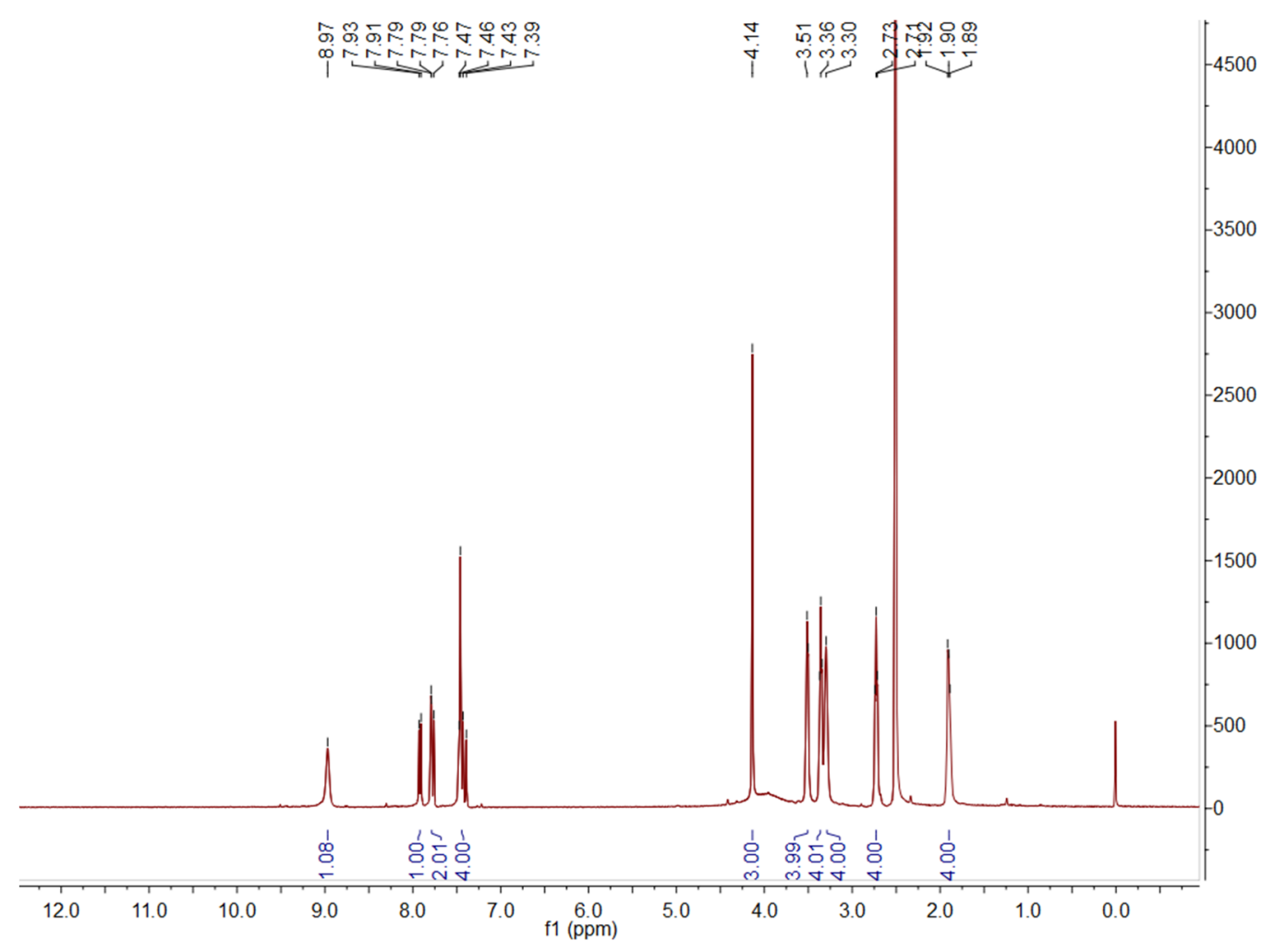

Figure S1. ${ }^{1} \mathrm{H}$ NMR spectrum of TASG.

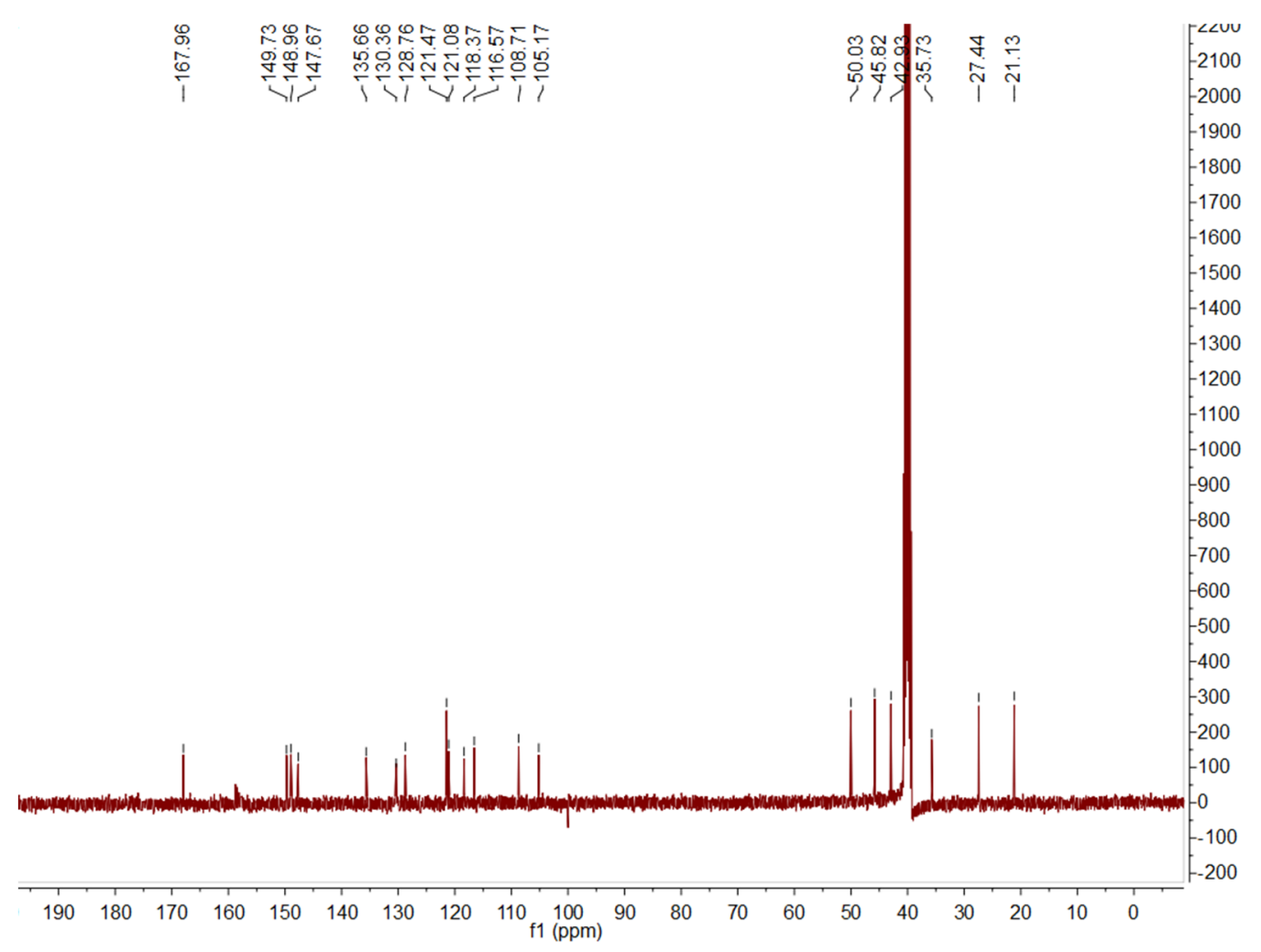

Figure S2. ${ }^{13} \mathrm{C}$ NMR spectrum of TASG. 


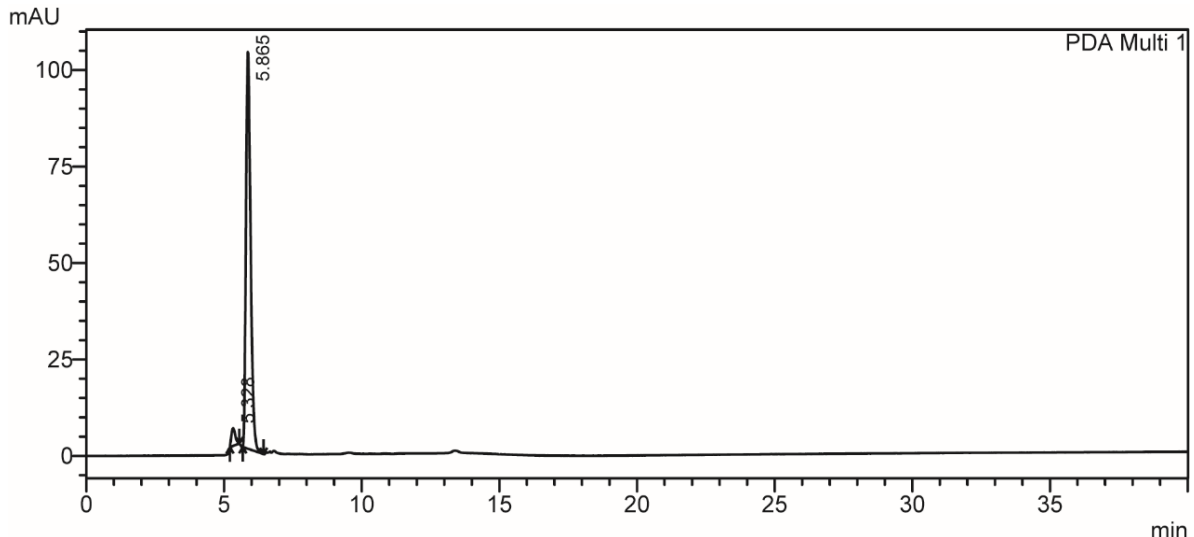

\begin{tabular}{|r|r|r|r|r|r|}
\hline \multicolumn{3}{|c|}{ PeakTable } \\
\hline PDA Ch1 254nm 4nm \\
\hline Peak\# & Ret. Time & Area & Height & Area \% & Height \% \\
\hline 1 & 5.328 & 45696 & 4572 & 3.622 & 4.259 \\
\hline 2 & 5.865 & 1215855 & 102785 & 96.378 & 95.741 \\
\hline Total & & 1261550 & 107357 & 100.000 & 100.000 \\
\hline
\end{tabular}

Figure S3. HPLC analysis of TASG.

$\begin{array}{rrr}\text { Error Margin (ppm): } 20 & \text { DBE Range: }-10.0-200.0 & \text { Electron lons: both } \\ \text { HC Ratio: } 0.0-20.0 & \text { Apply N Rule: no } & \text { Use MSn Info: no } \\ \text { Max Isotopes: all } & \text { Isotope RI (\%): } 1.00 & \text { Isotope Res: } 10000 \\ \text { MSn Iso RI (\%): } 75.00 & \text { MSn Logic Mode: AND } & \text { Max Results: } 1000\end{array}$
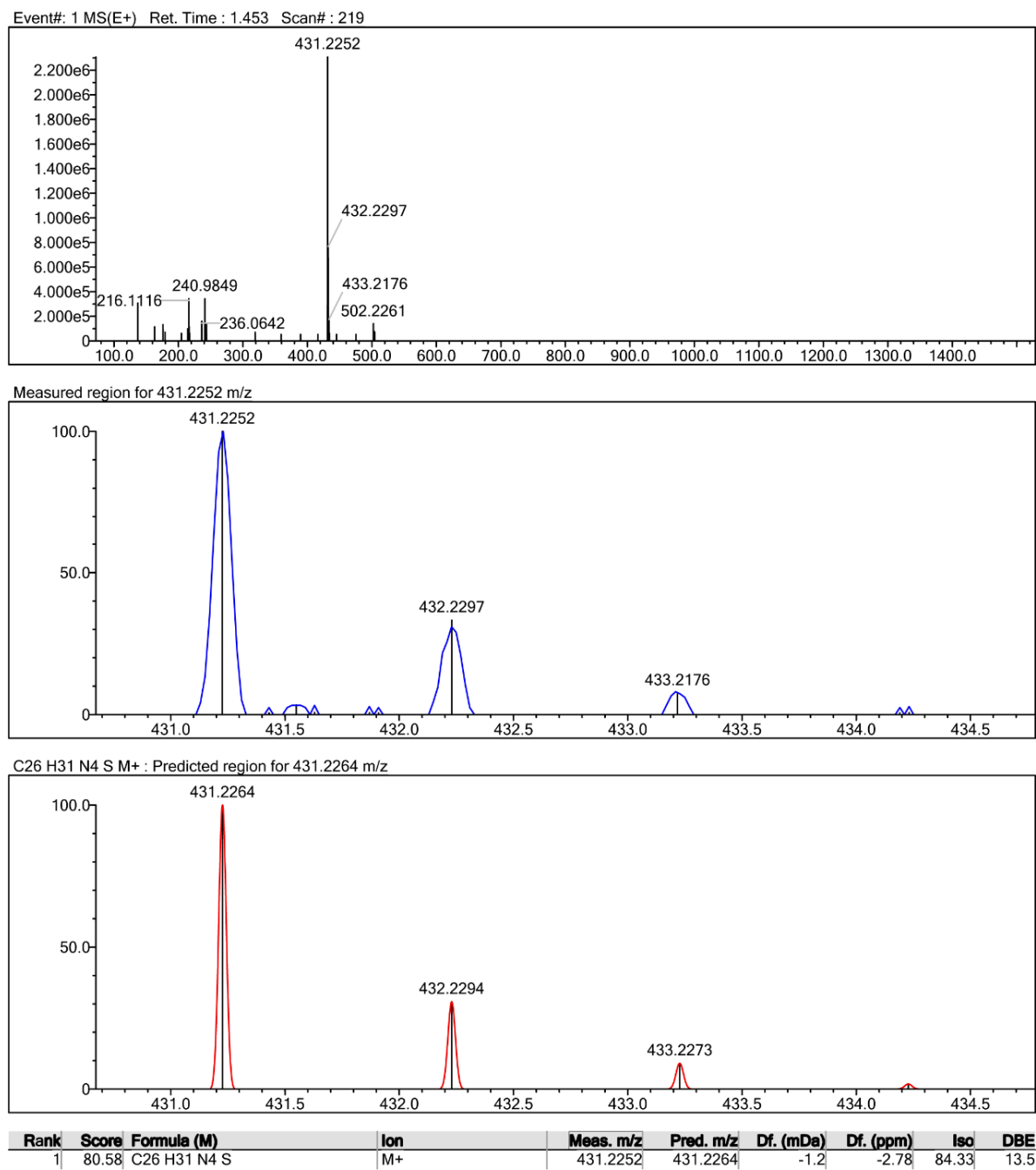

Figure S4. HRMS spectrum of TASG. 


\subsection{UV-Vis Absorption Studies}

UV-Vis absorption studies were performed on a UV-2600 spectrophotometer (Shimadzu, Japan). A quartz cuvette with a $1 \mathrm{~cm}$ path length was used for the recording of spectra in the range of 350-750 nm.

\subsection{Fluorescence Studies}

Fluorescence studies were performed on Fluoromax-4 Spectrofluorometer (HORIBA, Japan). A quartz cuvette with $2 \mathrm{~mm} \times 10 \mathrm{~mm}$ path length was used for the spectra recorded at $1 \mathrm{~nm}$ excitation and emission slit widths unless otherwise specified. The absolute fluorescence quantum yield $\left(\Phi_{\mathrm{F}}\right)$ of TASG was measured by Quanta-Phi module for Fluoromax-4 Spectrofluorometer. The fluorescence spectra in the range of 580-800 nm were recorded when excited at $560 \mathrm{~nm}$.

\subsection{Fixed Cell Staining Experiments}

The HeLa cells were grown in MEM media containing 10\% fetal bovine serum and cultured at $37^{\circ} \mathrm{C}$ in a $\mathrm{CO}_{2} /$ air $(5 \% / 95 \%)$ incubator. Cells were plated on glass bottom 96-well plate (MatTek) and grew overnight, then exposed to various stress conditions. ${ }^{1,2}$ For $\mathrm{NaAsO}_{2}$ stress, cells were treated with $500 \mu \mathrm{M}$ sodium arsenite for $1 \mathrm{~h}$ unless otherwise specified; for 2-DG stress, cells were treated with $100 \mathrm{mM}$ 2-deoxy-D-glucose for $1 \mathrm{~h}$ (About $60 \%$ of cells form SGs); for rotenone stress, cells were treated with $100 \mu \mathrm{M}$ rotenone for $2 \mathrm{~h}$ (About $48 \%$ of cells form SGs); for thapsigargin stress, cells were treated with $1 \mu \mathrm{M}$ thapsigargin for $1 \mathrm{~h}$; for heat shock stress, cells were transferred to $43^{\circ} \mathrm{C}$ for 1h. Then cells were fixed with $4 \%$ paraformaldehyde at room temperature for $20 \mathrm{~min}$. After rinsing with PBS for $5 \mathrm{~min}(3 \times)$, cells were stained with $0.5 \mu \mathrm{M}$ TASG and $0.5 \mu \mathrm{g} \cdot \mathrm{mL}^{-1}$ DAPI for $15 \mathrm{~min}$ at room temperature. For enzymes treatments, cells were permeabilized in 0.5\% TritonX-100/PBS at $37^{\circ} \mathrm{C}$ for $30 \mathrm{~min}$, and then incubated with 200 units $\cdot \mathrm{mL}^{-1}$ enzymes (RNase $\mathrm{A} / \mathrm{DNase} \mathrm{I}$ ) at $37^{\circ} \mathrm{C}$ for 4 h before staining. For the immunofluorescence of SG proteins, ${ }^{3}$ cells were blocked with 5\% BSA/PBS at $37^{\circ} \mathrm{C}$ for $30 \mathrm{~min}$. Cells were then incubated with primary antibodies: Anti-G3BP antibody (ab181150, abcam), Anti-TIA-1 antibody (ab140595, abcam) or Anti-FMRP antibody (ab128095, abcam) in PBS with $3 \%$ BSA at $4{ }^{\circ} \mathrm{C}$ overnight. Subsequently, cells were incubated with Alexa 488-conjugated antibody (A32731, Thermo Fisher Scientific) at $37^{\circ} \mathrm{C}$ for $1 \mathrm{~h}$. After washing with PBS for 5 min (3×), cells were stained with $0.5 \mu \mathrm{M}$ TASG and $0.5 \mu \mathrm{g} \cdot \mathrm{mL}^{-1}$ DAPI for $15 \mathrm{~min}$ at room temperature. The emission of TASG was collected under excitation at $640 \mathrm{~nm}$, and that of the antibodies was collected 
under excitation at $488 \mathrm{~nm}$, sequentially. Digital images were recorded using a FV3000 laser scanning confocal microscope (Olympus) with a $60 \times$ objective lens and analyzed with Fiji/ImageJ. The Pearson's correlation coefficient was calculated using Coloc 2 plugin.

\subsection{Live Cell Staining Experiments}

The HeLa cells were grown in MEM media containing $10 \%$ fetal bovine serum at $37^{\circ} \mathrm{C}$, with $5 \%$ $\mathrm{CO}_{2}$ atmosphere. Cells were plated on glass bottom 96-well plate (MatTek) and grew overnight. For the screening of small-molecule fluorescent probes for SGs, live HeLa cells expressing BFP-G3BP1 were stressed with $500 \mu \mathrm{M}$ sodium arsenite and then stained with $5 \mu \mathrm{M}$ candidate probes, such as TASG for $1 \mathrm{~h}$. For P-bodies imaging, HeLa cells expressing BFP-DCP1A were stained with $2 \mu \mathrm{M}$ TASG for $3 \mathrm{~h}$ and then stressed with $300 \mathrm{mM} \mathrm{NaCl}$ or $500 \mu \mathrm{M}$ sodium arsenite for $1 \mathrm{~h}$. For other experiments, cells were stained with $2 \mu \mathrm{M}$ TASG for $3 \mathrm{~h}$ and then stressed with various conditions as indicated in Section 1.4. The emission of TASG was collected under excitation at $640 \mathrm{~nm}$ unless otherwise specified. Digital images were recorded using a FV3000 laser scanning confocal microscope (Olympus) equipped with a $60 \times$ objective lens. Super-resolution images were acquired on a N-SIM microscope (Nikon) equipped with an Apochromat $100 \times / 1.49$ numerical aperture oil-immersion objective lens and analyzed with Fiji/ImageJ. The Pearson's correlation coefficient was calculated using Coloc 2 plugin.

\subsection{Plasmid Transfection}

cDNAs encoding BFP, GFP, G3BP1, DCP1A and nucleolin were obtained by gene synthesis from Convenience Biology. To generate BFP-tagged G3BP1, BFP-tagged DCP1A and GFP-tagged nucleolin protein, cDNAs were inserted into the pcDNA3.1 vector and the construct was confirmed by sequencing. Plasmid transfection of cells was performed using Lipofectamine 3000 (Invitrogen, USA) according to the manufacturer's instructions. $100 \mathrm{ng}$ of constructed plasmid were used per well of a glass bottom 96-well plate (MatTek) and then incubated at $37^{\circ} \mathrm{C}$ with $\mathrm{CO}_{2}$ for $24 \mathrm{~h}$.

\subsection{Cell Viability Studies}

HeLa Cells were seeded in 96-well plates $\left(5.0 \times 10^{3}\right.$ cells/ well $)$ and exposed to various concentrations of TASG. After a $24 \mathrm{~h}$ treatment, $10 \mu \mathrm{L}$ of $5 \mathrm{mg} / \mathrm{ml}$ methylthiazolyl tetrazolium (MTT) solution was added to each well, and cells were further incubated for $4 \mathrm{~h}$. The cells in each well were then treated with DMSO (100 $\mu \mathrm{L}$ per well), and the optical density (OD) was recorded at $570 \mathrm{~nm}$. All 
experiments were performed in parallel and in triplicate, and the $\mathrm{IC}_{50}$ values were derived from the curves of the mean OD values of the triplicate tests plotted against the drug concentration.

\subsection{RNA Extraction and Purification}

HeLa cells were seeded in $60 \mathrm{~mm}$ dishes $\left(1.5 \times 10^{6}\right.$ cells/dish $)$ and allowed to adhere overnight. Total RNA was isolated using the HiPure Total RNA Mini Kit (Magen) according to the manufacturer's instructions.

\subsection{Purification of GFP-G3BP1 Protein and Preparation of RNA-G3BP1 Condensates}

DNA fragments encoding G3BP1 and GFP were obtained by gene synthesis from Convenience Biology. GFP and G3BP1-coding DNA were ligated into the pET28a plasmid and the construct was confirmed by sequencing. For protein expression, GFP-G3BP1 full-length was expressed in BL21 (DE3) cells (TIANGEN) upon induction with $0.5 \mathrm{mM}$ Isopropyl $\beta$-D-thiogalactoside (IPTG, BioFroxx) overnight at $16^{\circ} \mathrm{C}$. The protein was purified through Ni Sepharose ${ }^{\mathrm{TM}} 6$ Fast Flow column (GE Healcare) as described previously. ${ }^{4}$ The purity of the GFP-G3BP1 was analyzed by $10 \%$ SDS-PAGE using coomassie blue staining and the protein concentration was measured by BCA Protein Assay Kit (Fdbio science). For RNA-G3BP1 condensates preparation, $30 \mu \mathrm{M}$ GFP-G3BP1 were incubated with $75 \mathrm{ng} /$ $\mu \mathrm{L}$ total RNA in $20 \mathrm{mM}$ PIPES buffer containing $85 \mathrm{mM} \mathrm{KCl}, 1 \mathrm{mM} \mathrm{MgCl}_{2}$ and 10\% PEG 6000, pH 7.0. Digital images were recorded using a FV3000 laser scanning confocal microscope (Olympus) equipped with a $60 \times$ objective lens and analyzed with Fiji/ImageJ.

\subsection{Purification of Mammalian Stress Granule Cores}

Hela cells expressing BFP-G3BP1 were grown to $85 \%$ confluency and then stained with $2 \mu \mathrm{M}$ TASG for $3 \mathrm{~h}$. Cell culture media was replaced with fresh complete MEM growth media $1 \mathrm{~h}$ prior to stress induction. Subsequently, cells were stressed with $500 \mu \mathrm{M}$ sodium arsenite for $1 \mathrm{~h}$ at $37^{\circ} \mathrm{C} / 5 \%$ $\mathrm{CO}_{2}$. Following sodium arsenite treatment, the media was aspirated, and cells were washed with PBS for $5 \mathrm{~min}(3 \times)$. The stress granule cores were then purified as described previously. ${ }^{5}$ Digital images were recorded using a FV3000 laser scanning confocal microscope (Olympus) equipped with a 60× objective lens and analyzed with Fiji/ImageJ.

\subsection{S. cerevisiae Staining Experiments}

S. cerevisiae cells (W303a) were grown at $30^{\circ} \mathrm{C}$ to an $\mathrm{OD}_{600}$ of 0.5 in yeast extract peptone 
dextrose (YPD) medium, then spined at $4000 \times \mathrm{g}$ for $20 \mathrm{~min}$ at room temperature to remove the supernatant. The pellet was re-suspended with PBS and stained with $2 \mu \mathrm{M}$ TASG for $2.5 \mathrm{~h}$. For heat shock treatment, cells were incubated in a $46^{\circ} \mathrm{C}$ water bath for $30 \mathrm{~min}$ prior to imaging. Digital images were recorded using a FV3000 laser scanning confocal microscope (Olympus) equipped with a 60× objective lens and analyzed with Fiji/ImageJ.

\subsection{Drosophila tissue Staining Experiments}

Drosophila was grown at $25^{\circ} \mathrm{C}$ in incubators set for a 12-h-light-12-h-dark schedule. Intestines dissected from female drosophila on normal diet were stained with $2 \mu \mathrm{M}$ TASG for $2.5 \mathrm{~h}$ in KRB buffer (R21692, Saint-Bio). For $\mathrm{NaAsO}_{2}$ treatment, intestines were stressed with $1 \mathrm{mM}$ arsenite for 60 min, then fixed with $4 \%$ paraformaldehyde at room temperature for $30 \mathrm{~min}$. After washing with PBS for $5 \mathrm{~min}(3 \times)$, intestines were stained with $0.5 \mu \mathrm{g} \cdot \mathrm{mL}^{-1}$ DAPI for $20 \mathrm{~min}$ at room temperature prior to imaging. Digital images were recorded using a FV3000 laser scanning confocal microscope (Olympus) equipped with a $60 \times$ objective lens and analyzed with Fiji/ImageJ.

\subsection{C. elegans Staining Experiments}

C. elegans were grown at $20^{\circ} \mathrm{C}$ on normal growth media (NGM) plates with OP50 (Escherichia coli). C. elegans were stained with $2 \mu \mathrm{M}$ TASG for $2.5 \mathrm{~h}$ in M9 buffer. For heat shock treatment, $C$. elegans were stressed at $35^{\circ} \mathrm{C}$ for different time prior to imaging. For recovery treatment, C. elegans were stressed at $35^{\circ} \mathrm{C}$ for $1 \mathrm{~h}$, then recovered on NGM plates at $20^{\circ} \mathrm{C}$ for different time prior to imaging. Digital images were recorded using a FV3000 laser scanning confocal microscope (Olympus) equipped with $60 \times$ or $100 \times$ objective lens and analyzed with Fiji/ImageJ.

\section{Materials}

Stock solution of TASG $(10 \mathrm{mM})$ was dissolved in DMSO and stored at $-80^{\circ} \mathrm{C}$. Further dilution of sample to working concentrations was made with relevant buffer prior to use. RNase A and DNase I were purchased from Ambion (USA). Lysozyme was purchased from BioFroxx (Germany). Proteinase K was purchased from YEASEN (China). Hoechst 33342 and DAPI were purchased from Sigma (USA). Sodium arsenite was purchased from Sigma (USA). 2-DG was purchased from Selleck (USA). Rotenone was purchased from Sigma (USA). Thapsigargin was purchased from Beyotime (China). 


\section{Other Supporting Table, Spectra and Graphs}

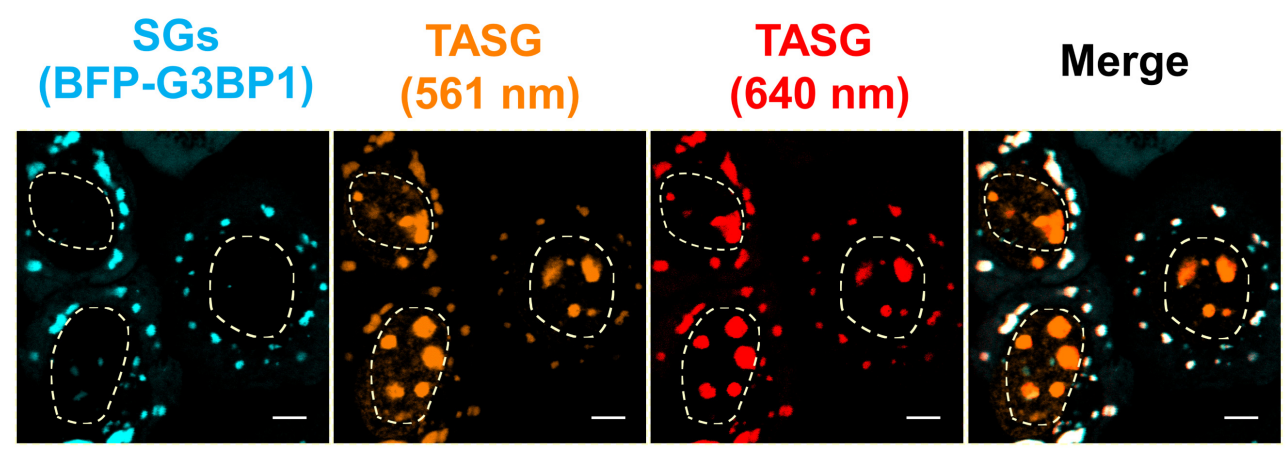

Figure S5. Imaging of live HeLa cells treated with sodium arsenite and then stained with TASG (5 $\mu \mathrm{M}$, red). The emission of TASG was collected under excitation at $561 \mathrm{~nm}$ and $640 \mathrm{~nm}$, respectively. SGs are indicated by BFP-tagged G3BP1 (cyan). The nucleus is outlined by a dashed white line. Scale bars: $5 \mu \mathrm{m}$.

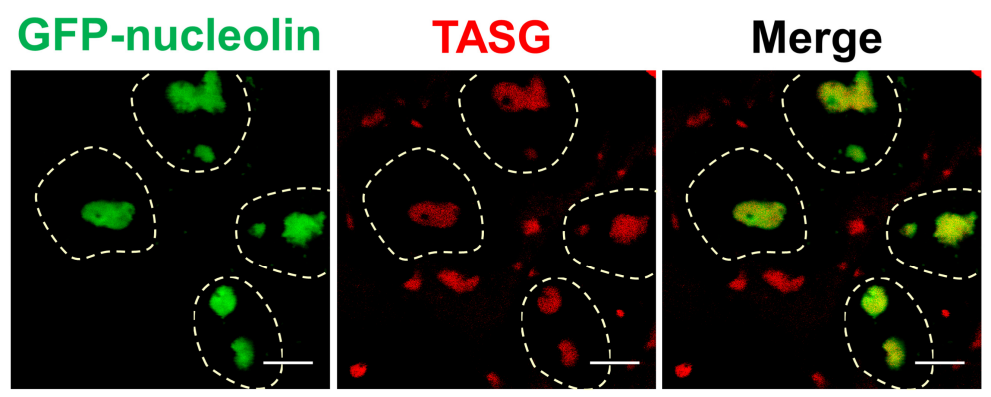

Figure S6. Imaging of live HeLa cells treated with sodium arsenite and stained with TASG $(2 \mu \mathrm{M}$, red). The nucleoli are indicated by GFP-tagged nucleolin (Green). ${ }^{6}$ Scale bars: $5 \mu \mathrm{m}$.

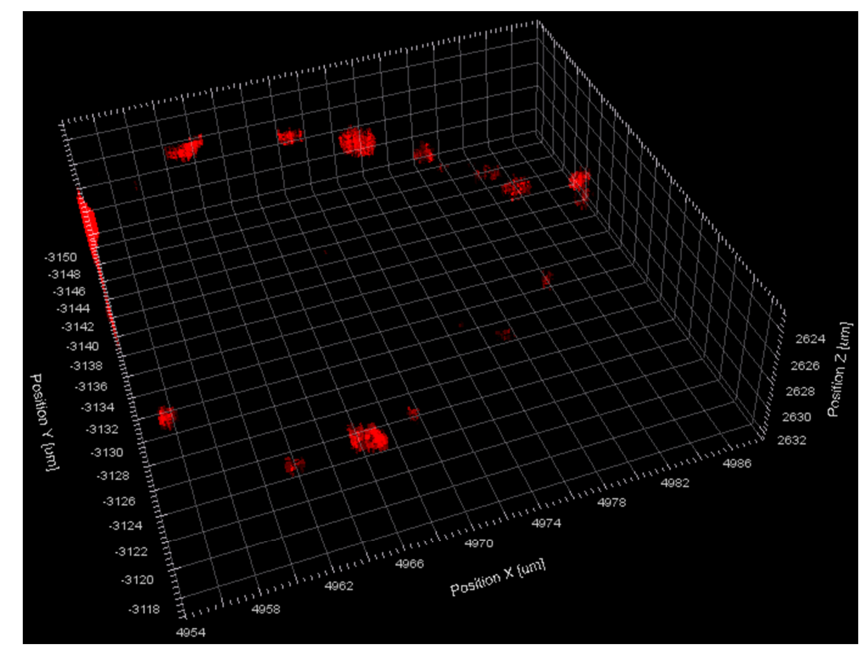

Figure S7. 3D-SIM imaging of live HeLa cells treated with sodium arsenite and stained with TASG (2 $\mu \mathrm{M}$, red). 


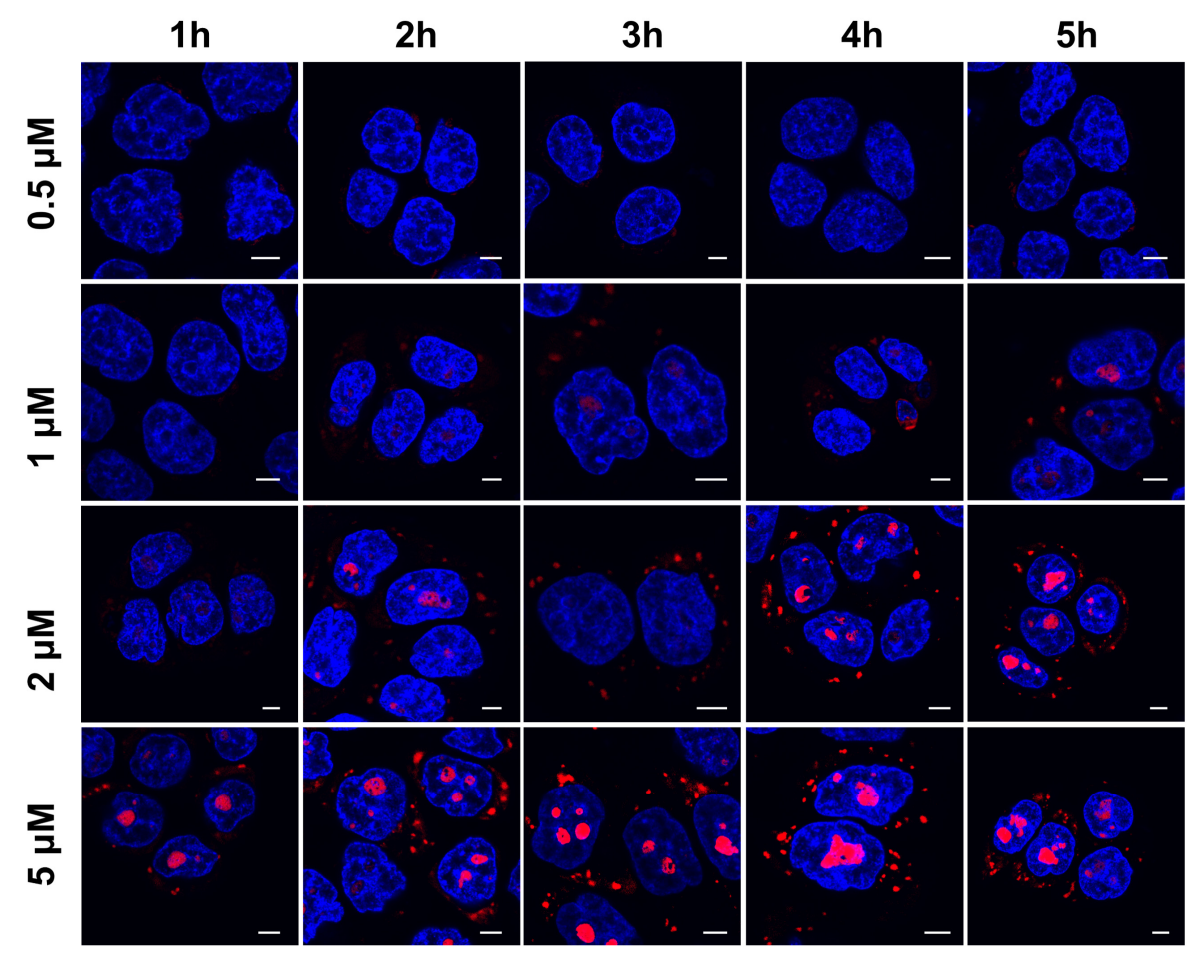

Figure S8. Imaging of live HeLa cells stained with TASG (red) in variant concentrations and incubation times. Live HeLa cells were stressed with sodium arsenite. The nucleus is visualized by Hoechst 33342 staining (blue). Scale bars: $5 \mu \mathrm{m}$.
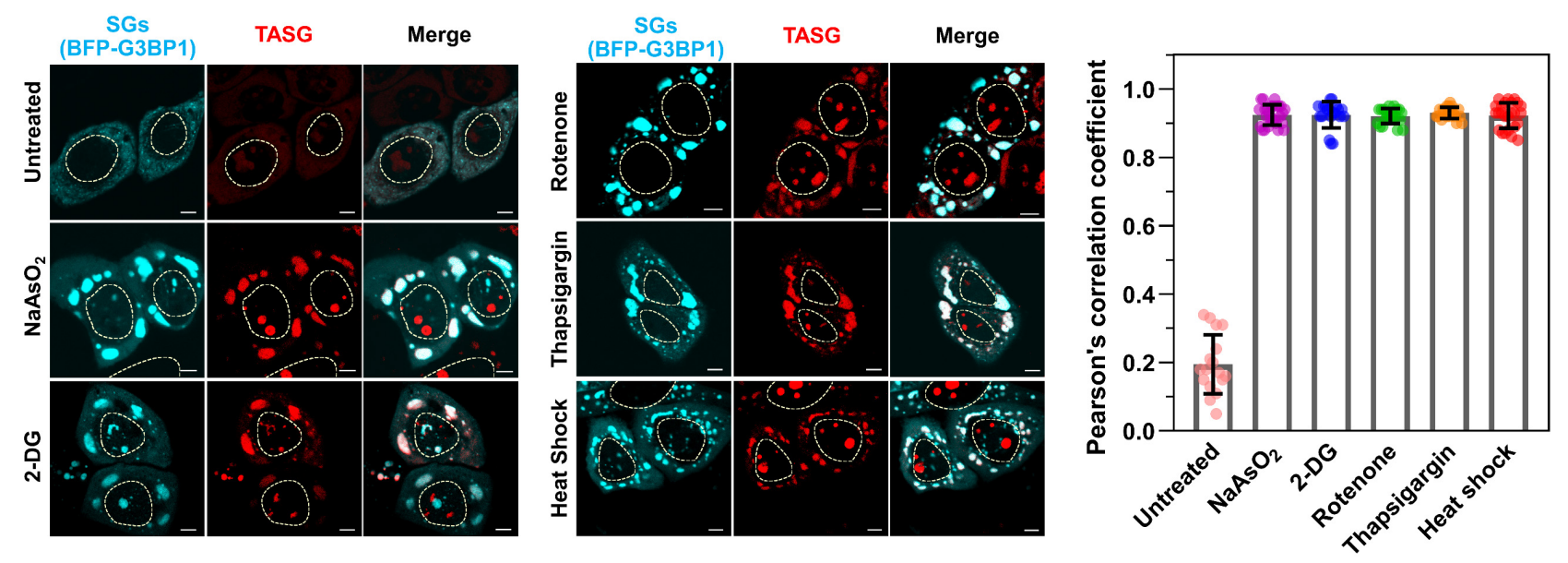

Figure S9. Imaging of live HeLa cells treated without or with various stress-inducing agents (sodium arsenite, 2-DG, rotenone and thapsigargin) and heat shock and stained with TASG ( $2 \mu \mathrm{M}$, red). SGs are indicated by BFP-tagged G3BP1 (cyan). The nucleus is outlined by a dashed white line. Pearson's correlation coefficient is used to quantify the degree of colocalization between TASG and SGs in the cytoplasm (untreated: $0.19 \pm 0.09$; sodium arsenite: $0.92 \pm 0.03$; 2-DG: $0.92 \pm 0.04$; rotenone: $0.92 \pm 0.02$; thapsigargin: $0.93 \pm 0.02$; heat shock: $0.92 \pm 0.04$ ). Approximately 20 cells were measured. Biological replicates $(n=3)$ were taken. The data are presented as mean \pm SD. Scale bars: $5 \mu \mathrm{m}$. 

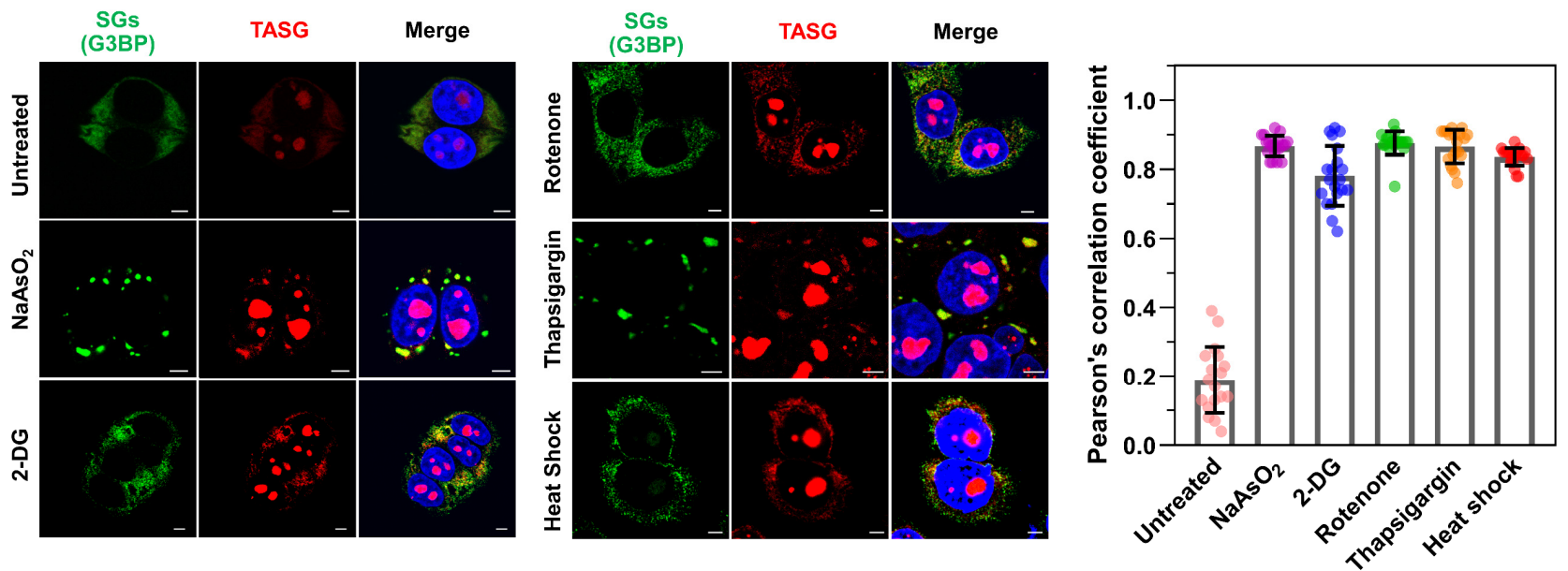

Figure S10. Imaging of fixed HeLa cells treated without or with various stress-inducing agents (sodium arsenite, 2-DG, rotenone and thapsigargin) and heat shock then stained with TASG $(0.5 \mu \mathrm{M}$, red). SGs are indicated by immunofluorescence staining against G3BP (green). The nucleus is visualized by DAPI staining (blue). Pearson's correlation coefficient is used to quantify the degree of colocalization between TASG and SGs in the cytoplasm (untreated: $0.19 \pm 0.10$; sodium arsenite: 0.87 \pm 0.03 ; 2-DG: $0.78 \pm 0.09$; rotenone: $0.88 \pm 0.03$; thapsigargin: $0.87 \pm 0.05$; heat shock: $0.84 \pm 0.03$ ) Approximately 20 cells were measured. Biological replicates $(n=3)$ were taken. The data are presented as mean \pm SD. Scale bars: $5 \mu \mathrm{m}$.

A

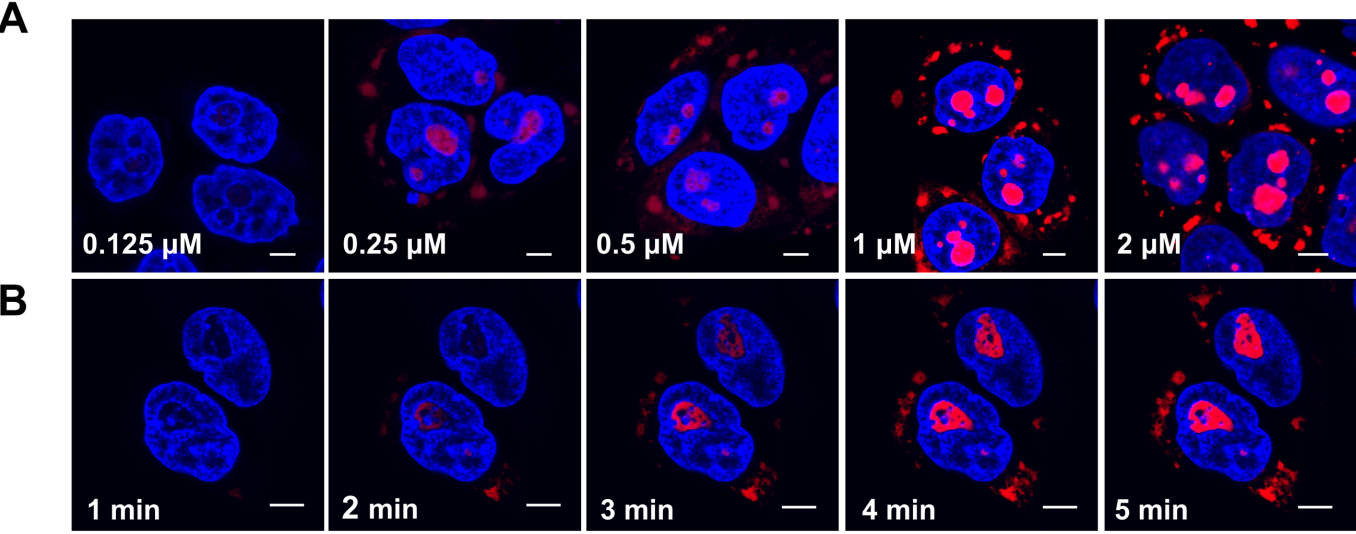

Figure S11. Imaging of fixed HeLa cells stained with TASG (red). (A) Imaging of fixed HeLa cells stained by TASG with different concentrations. (B) Imaging of fixed HeLa cells stained by $0.5 \mu \mathrm{M}$ TASG during a period of $5 \mathrm{~min}$. Live HeLa cells were stressed with sodium arsenite before fixed. The nucleus is visualized by DAPI staining (blue). Scale bars: $5 \mu \mathrm{m}$. 


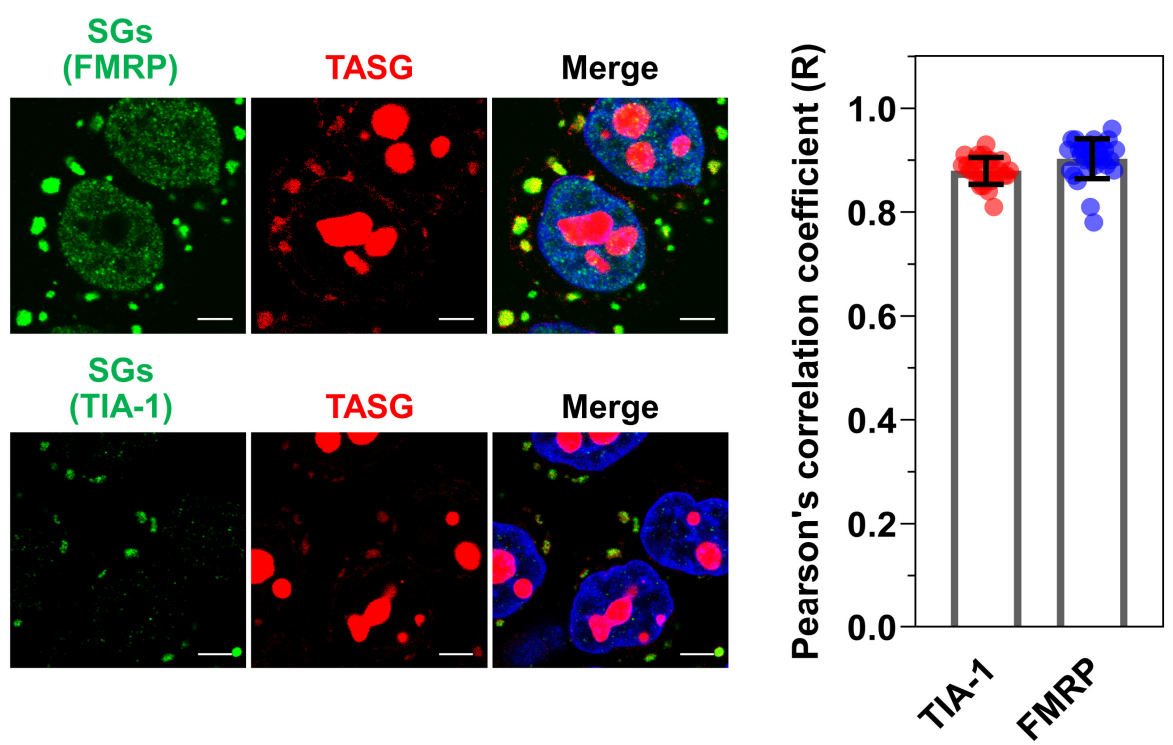

Figure S12. Imaging of fixed HeLa cells treated with sodium arsenite and then stained with TASG (0.5 $\mu \mathrm{M}$, red). SGs are indicated by immunofluorescence staining against TIA-1 or FMRP (green). The nucleus is visualized by DAPI staining (blue). Pearson's correlation coefficient is used to quantify the degree of colocalization between TASG and SGs in the cytoplasm (TIA-1: $0.88 \pm 0.03$; FMRP: $0.90 \pm 0.04)$. Approximately 20 cells were measured. Biological replicates $(n=3)$ were taken. The data are presented as mean \pm SD. Scale bars: $5 \mu \mathrm{m}$.
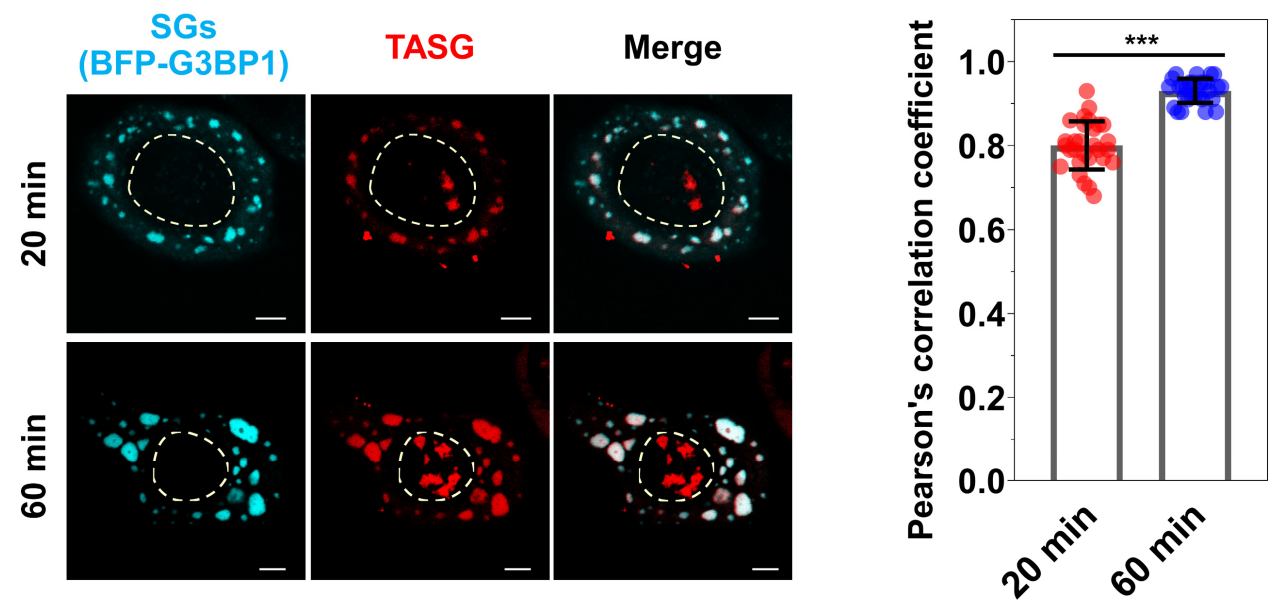

Figure S13. Imaging of live HeLa cells treated with sodium arsenite for 20 or $60 \mathrm{~min}$ and stained with TASG $(2 \mu \mathrm{M}$, red). SGs are indicated by BFP-tagged G3BP1 (cyan). The nucleus is outlined by a dashed white line. Pearson's correlation coefficient is used to quantify the degree of colocalization between TASG and SGs in the cytoplasm. Approximately 20 cells were measured. Biological replicates $(n=3)$ were taken. The data are presented as mean $\pm S D$, and statistical significance was determined by the $t$ test as (ns) not significant, (*) $P<0.05$, (**) $P<0.01$, and (***) $P<0.001$. Scale bars: $5 \mu \mathrm{m}$. 
A

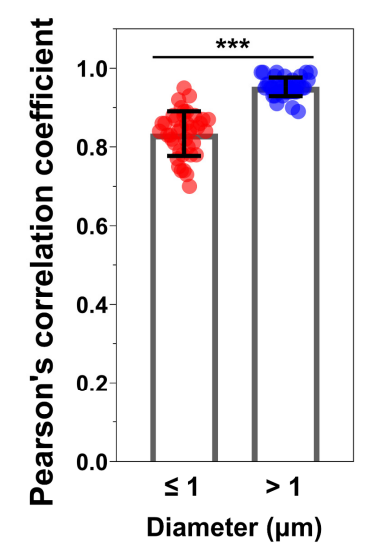

B

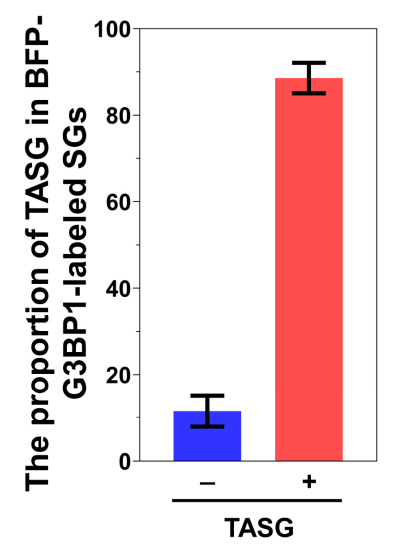

C

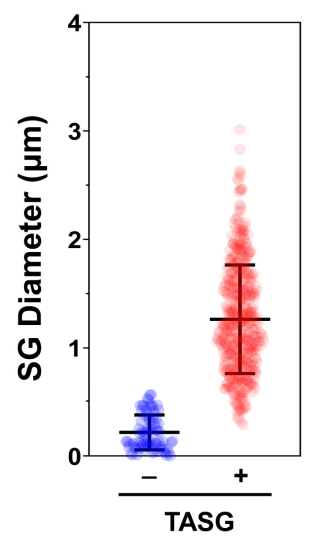

Figure S14. (A) Quantification of the degree of colocalization between TASG and SGs with different size in the cytoplasm using Pearson's correlation coefficient. (B) The proportion of TASG-negative and TASG-positive SGs were measured by the quantification of TASG foci inside BFP-G3BP1 foci. (C) Quantification of the diameter of TASG-negative and TASG-positive SGs. Live HeLa cells were treated with sodium arsenite for $1 \mathrm{~h}$ and stained with TASG $(2 \mu \mathrm{M})$. SGs are indicated by BFP-tagged G3BP1. Approximately 20 cells were measured. Biological replicates $(n=3)$ were taken. The data are presented as mean $\pm \mathrm{SD}$, and statistical significance was determined by the $t$ test as (ns) not significant, (*) $P<0.05,(* *) P<0.01$, and (***) $P<0.001$.
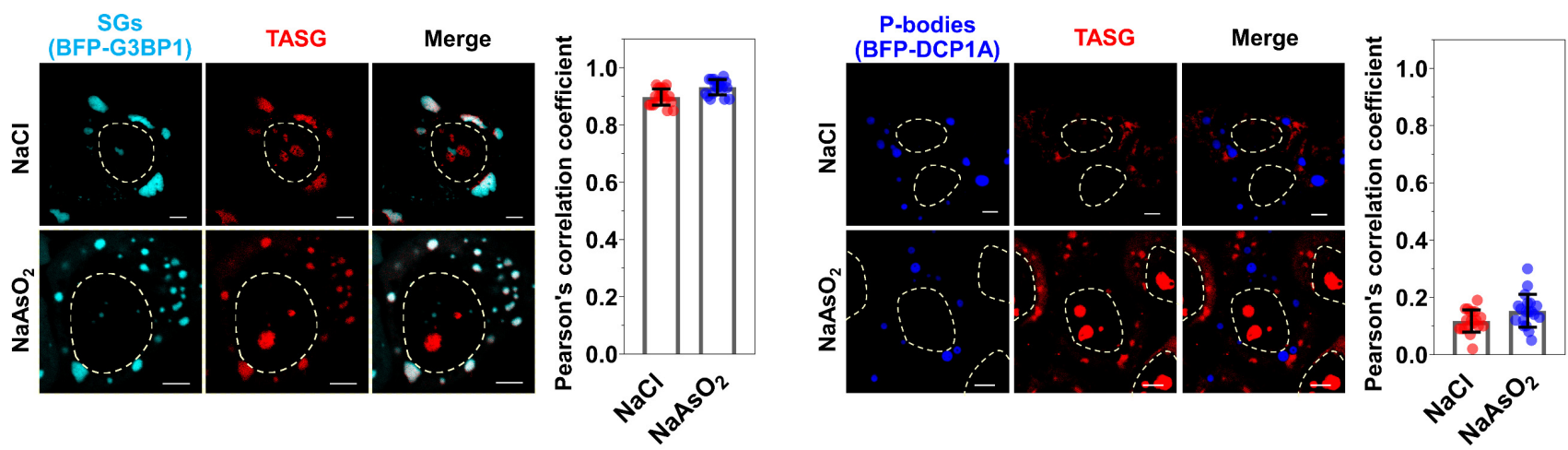

Figure S15. Imaging of live HeLa cells treated with $\mathrm{NaCl}(300 \mathrm{mM})$ or sodium arsenite $(500 \mu \mathrm{M})$ and stained with TASG (2 $\mu \mathrm{M}$, red). SGs and P-bodies are indicated by BFP-tagged G3BP1 (cyan) and BFP-tagged DCP1A (blue), respectively. ${ }^{7}$ The nucleus is outlined by a dashed white line. Pearson's correlation coefficient is used to quantify the degree of colocalization between TASG and SGs/Pbodies in the cytoplasm. Approximately 20 cells were measured. Biological replicates $(n=3)$ were taken. The data are presented as mean \pm SD. Scale bars: $5 \mu \mathrm{m}$. 


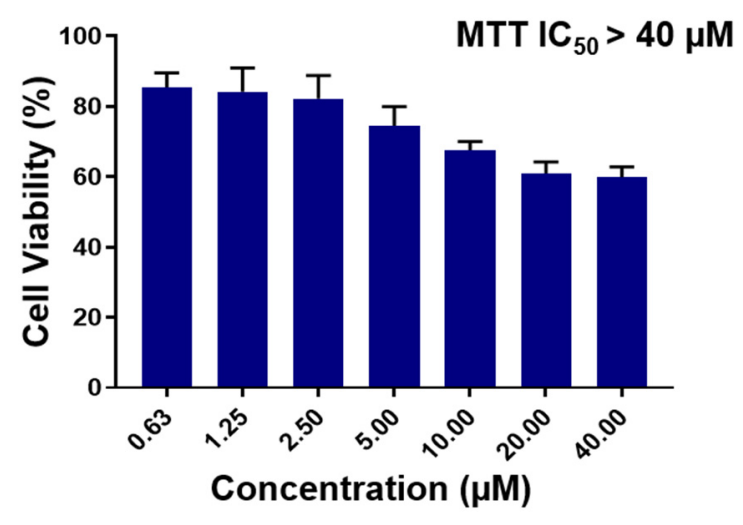

Figure S16. Viability of HeLa cells exposed to different concentrations of TASG for $24 \mathrm{~h}$ determined by MTT assay.

A

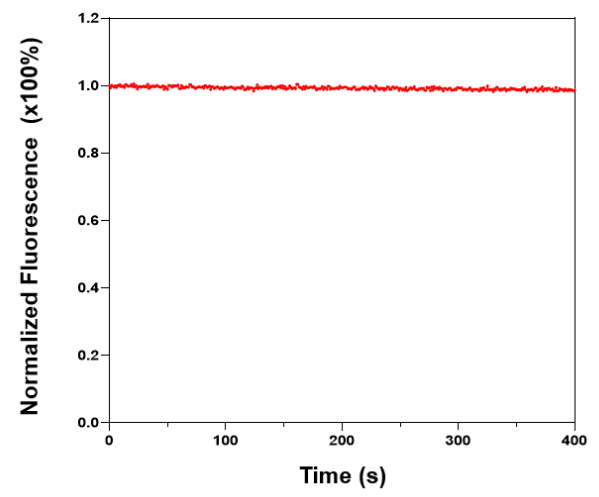

B

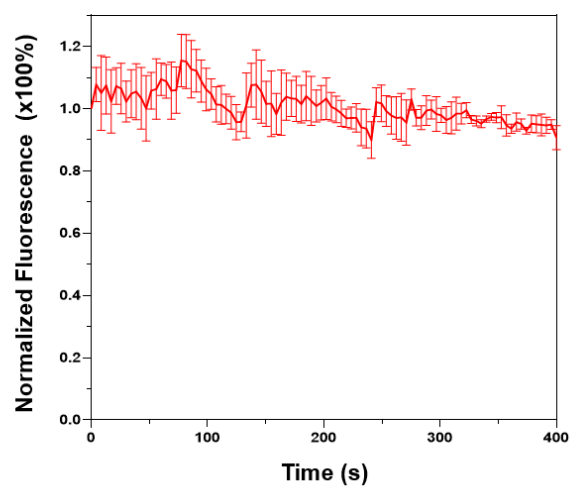

Figure S17. Photostability of TASG. (A) The normalized fluorescence intensity at $640 \mathrm{~nm}$ of $5 \mu \mathrm{M}$ TASG with complexes of $75 \mathrm{ng} / \mu \mathrm{L}$ RNA and $30 \mu \mathrm{M}$ GFP-G3BP1 under continuous excitation at 560 nm. (B) Quantitation of TASG fluorescence in stressed HeLa cells. The intensities change slightly, indicating that the TASG is photostable.

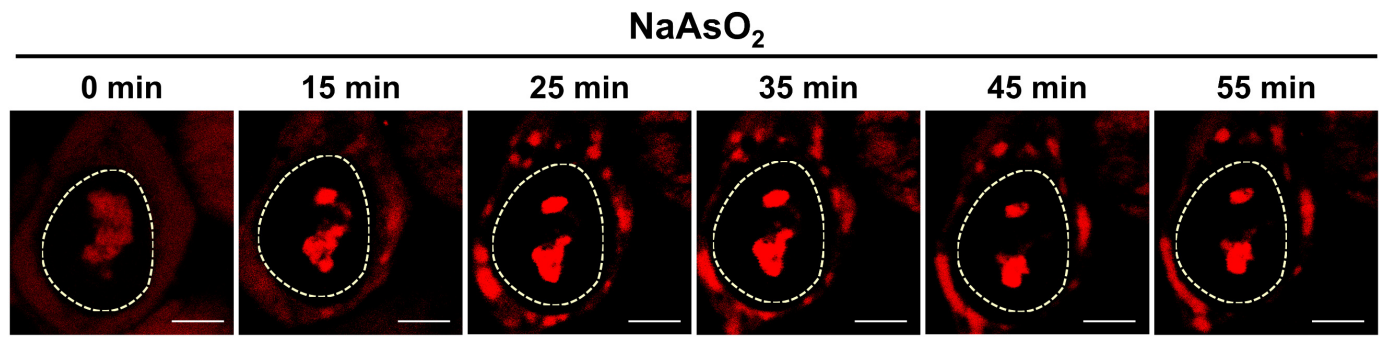

Figure S18. Time-lapse imaging of SG dynamics in live HeLa cells by TASG staining during a period of around $1 \mathrm{~h}$. Live HeLa cells were stressed with sodium arsenite. The nucleus is outlined by a dashed white line. Scale bars: $5 \mu \mathrm{m}$ 


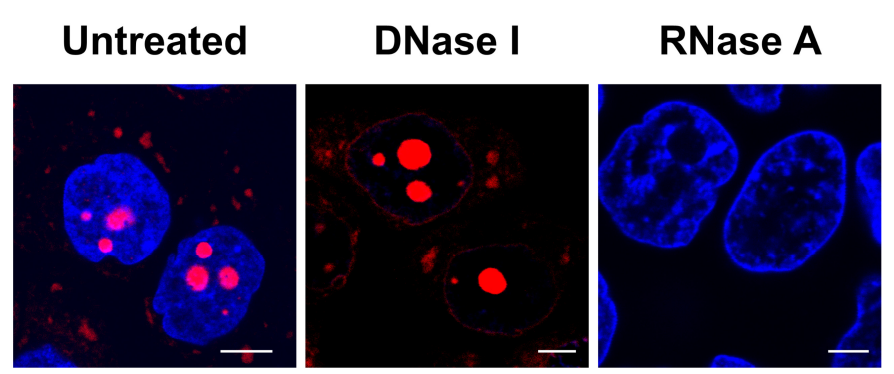

Figure S19. Imaging of fixed HeLa cells stained with $0.5 \mu \mathrm{M}$ TASG without and with DNase I or RNase A treatment. Live HeLa cells were stressed with sodium arsenite before fixed. The nucleus is visualized by DAPI staining (blue). Scale bars: $5 \mu \mathrm{m}$.

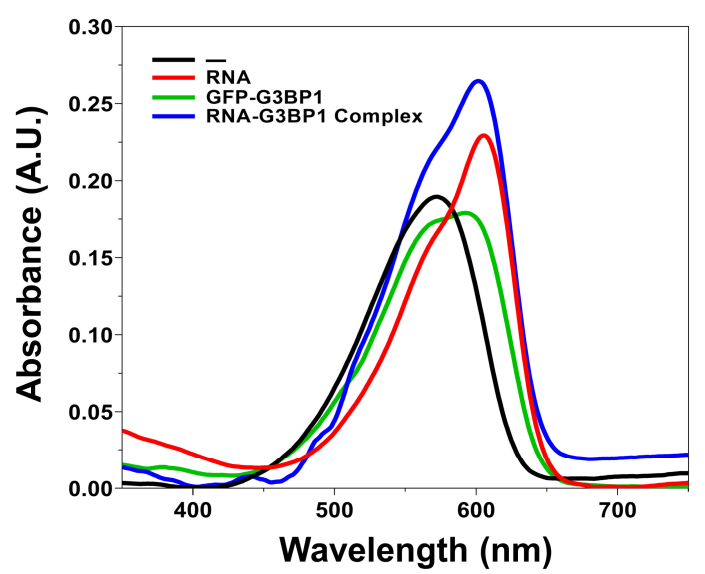

Figure S20. UV spectra of $5 \mu \mathrm{M}$ TASG without or with $75 \mathrm{ng} / \mu \mathrm{L}$ RNA, $30 \mu \mathrm{M}$ GFP-G3BP1 and their complexes in $20 \mathrm{mM}$ PIPES buffer, $85 \mathrm{mM} \mathrm{KCl,} 1 \mathrm{mM} \mathrm{MgCl}_{2}$ and 10\% PEG 6000, pH 7.0.

Table S1. Fluorescence quantum yields $\left(\Phi_{\mathrm{F}}\right)$ of TASG with or without $75 \mathrm{ng} / \mu \mathrm{L}$ RNA, $30 \mu \mathrm{M}$ GFPG3BP1 or their complexes in $20 \mathrm{mM}$ PIPES buffer containing $85 \mathrm{mM} \mathrm{KCl}, 1 \mathrm{mM} \mathrm{MgCl} 2$ and $10 \%$ PEG 6000, pH 7.0. These results are consistent with the trends observed in the fluorescence experiments.

\begin{tabular}{lll}
\hline Solution & $\boldsymbol{\Phi}_{\mathbf{F}}$ & Relative $\boldsymbol{\Phi}_{\mathbf{F}}$ \\
\hline Buffer & 0.023 & 1.0 \\
GFP-G3BP1 & 0.194 & 8.4 \\
RNA & 0.412 & 17.9 \\
GFP-G3BP1/RNA complex & 0.622 & 27.0 \\
\hline
\end{tabular}


A

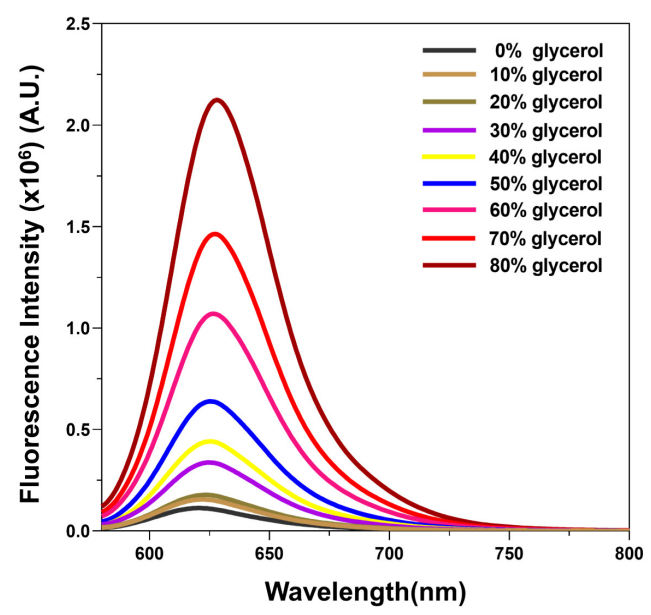

B

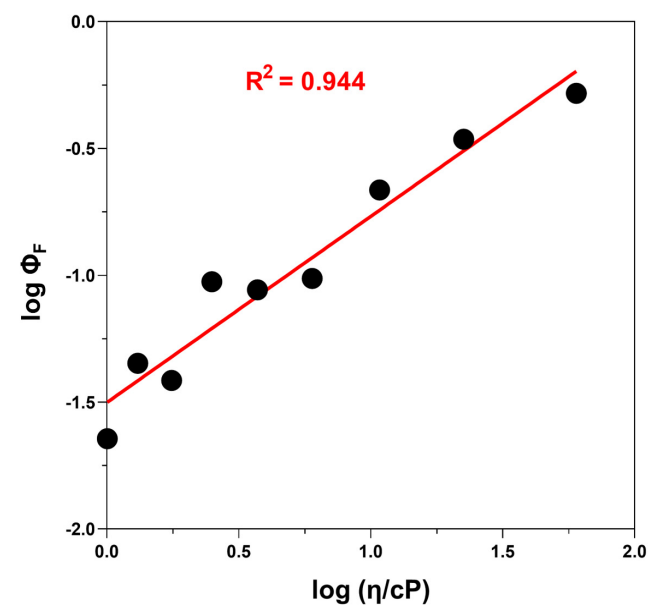

Figure S21. Viscosity dependent fluorescence of TASG. (A) The spectra of TASG in glycerol-water mixed solution. (B) Plot of the fluorescence quantum yield for TASG versus solvent viscosity. TASG exhibits negligible fluorescence in low-viscosity solutions but strong fluorescence in high-viscosity glycerol solvent. Logarithm of fluorescence quantum yields are correlated with logarithm of solvent viscosity.

A

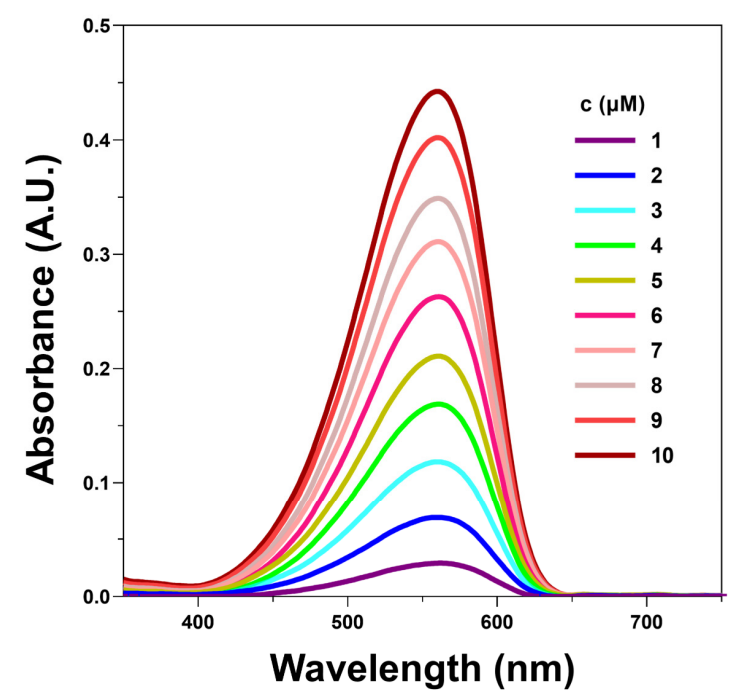

B

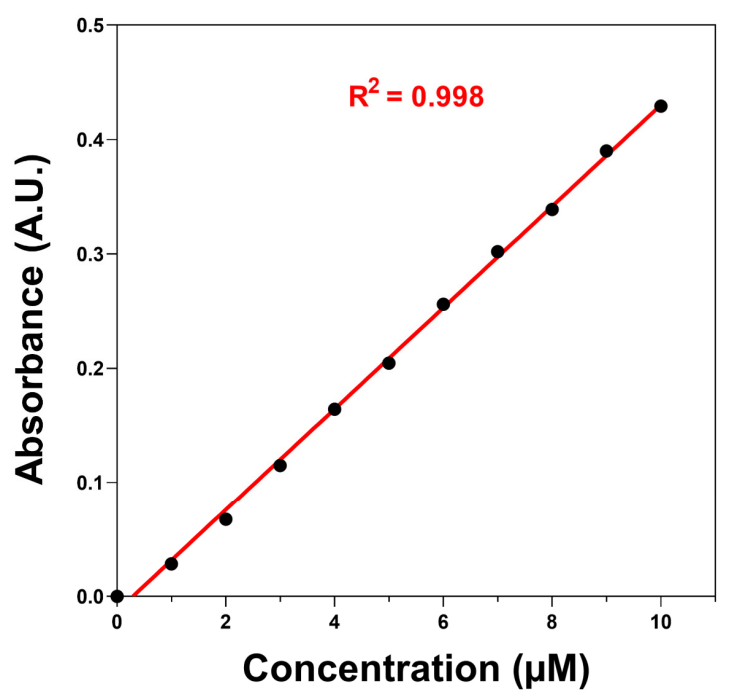

Figure S22. Concentration-Dependent UV-Vis absorbance of TASG. All of the spectra were collected in $20 \mathrm{mM}$ PIPES buffer containing $85 \mathrm{mM} \mathrm{KCl}, 1 \mathrm{mM} \mathrm{MgCl} 2, \mathrm{pH} 7.0$. (A) The spectra of TASG at different concentrations. (B) The absorbance of TASG at $560 \mathrm{~nm}$ showed that the variations follow the Beer-Lambert law. TASG had little propensity to aggregate in buffer according to its concentrationdependent absorbance spectra. 


\section{Reference}

(1) Marcelo, A.; Koppenol, R.; de Almeida, L. P.; Matos, C. A.; Nobrega, C. Cell Death Dis. 2021, 12, 592.

(2) Vanderweyde, T.; Youmans, K.; Liu-Yesucevitz, L.; Wolozin, B. Gerontology 2013, 59, 524-533.

(3) Protter, D. S.; Parker, R. Trends Cell Biol. 2016, 26, 668-679.

(4) Guillen-Boixet, J.; Kopach, A.; Holehouse, A. S.; Wittmann, S.; Jahnel, M.; Schlussler, R.; Kim, K.; Trussina, I.; Wang, J.; Mateju, D.; Poser, I.; Maharana, S.; Ruer-Gruss, M.; Richter, D.; Zhang, X.; Chang, Y. T.; Guck, J.; Honigmann, A.; Mahamid, J.; Hyman, A. A.; Pappu, R. V.; Alberti, S.; Franzmann, T. M. Cell 2020, 181, 346-361.

(5) Khong, A.; Jain, S.; Matheny, T.; Wheeler, J. R.; Parker, R. Methods 2018, 137, 49-54.

(6) Pick, R.; Badura, S.; Boesser, S.; Zoernig, M. Biochem. Biophys. Res. Commun. 2006, 349, 1329-1338.

(7) Jalihal, A. P.; Pitchiaya, S.; Xiao, L.; Bawa, P.; Jiang, X.; Bedi, K.; Parolia, A.; Cieslik, M.; Ljungman, M.; Chinnaiyan, A. M.; Walter, N. G. Mol. Cell 2020, 79, 978-990. 